\title{
Conservation priorities for endangered coastal North African Pennisetum glaucum L. landrace populations as inferred from phylogenetic considerations and population structure analysis
}

\author{
Mériam Ben Romdhane ${ }^{1} \cdot$ Leila Riahi $^{1,2} \cdot$ Badra Bouamama $^{1} \cdot$ Hela Houissa $^{1} \cdot$ Abdelwahed Ghorbel $^{1} \cdot$ \\ Néjia Zoghlami ${ }^{1}$
}

Received: 28 July 2017 / Revised: 2 April 2018 / Accepted: 18 April 2018 / Published online: 14 June 2018

(c) The Genetics Society 2018

\begin{abstract}
The increasing anthropologic pressure and the modernization of agriculture have led to a forsaking of pearl millet traditional cultivars, inducing a progressive loss of the genetic variability encompassed in this locally adapted germplasm. Imperatively, national efforts based on robust data gleaned from genetic surveys have to be undertaken in order to set up suitable conservation priorities. In this study, in addition to the assessment of the genetic diversity and population structure among and within a set of seven pearl millet landrace populations from coastal North Africa, demographic and phylogenetic data, conservation priority scores were calculated according to Vane-Wright et al. (1991). To date, genetic diversity of pearl millet in North Africa is still poorly documented. The present survey reports for the first time the use of highly informative nSSR markers $(\mathrm{PIC}=0.74)$ on Pennisetum glaucum landraces representative of the Mediterranean coastline of North Africa. A high level of genetic diversity was obtained within the investigated landraces $\left(H_{\mathrm{e}}=0.80\right)$ at the population level. $F_{\mathrm{ST}}$, AFC3D, and Bayesian clustering underlined significant differentiation and an apparent genetic structure, according to geographical origin. Phylogenetic considerations integrated with demographic and genetic information enabled conclusive inferences of highly prioritized populations for conservation. Populations Haouaria, Hammem Laghzez, Mahdia, and Medenine, representatives of the main pearl millet growing areas in Tunisia and cultivated in the North African littoral, should be strongly recommended for an ex situ conservation program. Dynamic on-farm conservation method is also required as it allows the local landraces to evolve in different environments, while maintaining their adaptation potentials.
\end{abstract}

\section{Introduction}

Pennisetum glaucum L. $(2 n=2 X=14$, Poaceae family) known as pearl millet is an annual multipurpose crop cultivated worldwide for grain, stover, and fodder (Gupta et al. 2015). This staple crop is growing mainly in the arid and

Electronic supplementary material The online version of this article (https://doi.org/10.1038/s41437-018-0091-0) contains supplementary material, which is available to authorized users.

Mériam Ben Romdhane

meriambenromdhane13@gmail.com

1 Laboratory of Plant Molecular Physiology (LPMP), Biotechnology Center of Borj-Cedria (CBBC), BP 901, 2050 Hammam-lif, Tunisia

2 Laboratory of Biotechnology and Bio-Geo Resources Valorization BVBGR-LR11ES31, University of Manouba, ISBST, Biotechpole Sidi Thabet, 2020 Ariana, Tunisia semi-arid areas of Africa and Asia in a vast range of marginal lands characterized by frequent drought periods and poor soil fertility (Chakauya 2002; Tako et al. 2015). The species $P$. glaucum L. is also cultivated in America and Australia as a summer forage and mulch component with high quality (FAO 2005).

Pearl millet cereal is of considerable interest for poor people living in the harsh conditions in Western India and the African Sahel, where it constitutes a complementary food for infants and young children (Kodkany et al. 2013; Pucher et al. 2014). In some of the driest and hottest regions of India and Africa, where agriculture is almost impossible, pearl millet plays a critical role in food security (Senthilvel et al. 2008; Elsadig et al. 2016). Pearl millet grains have high nutritional values, especially important amino and fatty acids contents, essential minerals, and vitamins appropriate for human nutrition (Yang et al. 2012; Manwaring et al. 2016). Additionally, this crop is used in brewing opaque beer and in preparing traditional dishes (Loumerem et al. 
2008). Previous investigations had revealed that oil and phenolics extracted from $P$. glaucum are a source of allelochemicals (Radhouane 2014) and have antibacterial and antioxidative properties (Marmouzi et al. 2016).

Africa is the recognized origin and center of diversity of pearl millet, where it was domesticated since prehistoric times along the Sahelian zone from Senegal to Sudan (Oumar et al. 2008; Manning et al. 2011). Later, this plant crop was introduced through maritime trades into other regions of the world as south Asia, eastern and southern Africa (National Research Council 1996). Somewhat later, in about the 8th Century, this cereal was introduced in the North African countries (Tostain 1998).

The North African pearl millet cultivation is principally delimited in continental areas as the southern region of Algeria (Tidikilet and Hagga) (Lemgharbi et al. 2016) and the Southwestern area of Libya (Sabha) (Mhana et al. 2017), both belonging to the Saharan landscape. However, in Tunisia, the production of this staple crop is mainly concentrated in coastal regions as the peninsula of Cap Bon (Northeast), in Mahdia (Centre), and in the coastal southeastern areas (Oumar et al. 2005; Radhouane 2011). The Kairouan region is the only continental representative of pearl millet culture in Tunisia. Situated in the highest point of the African continent and bordering the Mediterranean Sea from two sides, Tunisia with its north-south extent is endowed with a wide repository of plant resources adapted to the different dynamic climate zones covering the total land area (Hana et al. 2016). For P. glaucum, the Tunisian germplasm is today represented by traditional landraces that are still growing and well acclimated to poor soils and brackish water, which make this germplasm a useful basis for future breeding and improvement programs aiming to select high yielding varieties with high tolerance to environmental and edaphic conditions (Loumerem et al. 2008). Compared to cultivars, landraces are seen as storehouses of valuable genetic diversity, and are expected to have higher adaptation potentials (Bashir et al. 2015). Thus, landrace gene pools can be utilized for further genetic improvement of the species.

Pearl millet species was reported to display a high rate of out-crossing system reaching $90 \%$ and exhibits a high amount of diversity at both phenotypic and genotypic levels (Wilson et al. 1990). The high level of genetic diversity for $P$. glaucum was confirmed by previous studies based on quantitative (Loumerem et al. 2008; Lemgharbi et al. 2016), isozyme (Oumar et al. 2005), AFLP (Vom Brocke et al. 2003), RFLP (Bhattacharjee et al. 2002), RAPD (Govindaraj et al. 2009), and SSR molecular markers (Oumar et al. 2008; Bashir et al. 2015).

Despite the interest given to this species, pearl millet has not yet received the attention that it deserves in Tunisia. Increasingly, its old seeds are being replaced by high yielding lines and marginalized in favor of wheat and barley (Oumar et al. 2005), leading to genetic erosion. Besides, there were no earlier investigation exploring the genetic diversity and structure of Tunisian germplasm at the molecular level.

An efficient assessment of the genetic diversity within and between the populations of this species is required when conservation plans are envisioned. Furthermore, genetic surveys enable the creation of core collections and in situ germplasm management (Mariac et al. 2006).

This is the first detailed investigation that undertakes the molecular characterization and genetic analysis of local germplasms of coastal North African P. glaucum L. landrace populations based on nuclear SSR molecular markers. The aims of this investigation are to assess the genetic diversity and differentiation among a set of seven landrace populations harvested from the main repartition areas of this species in Tunisia, by means of informative microsatellites markers, and to establish suitable conservation priorities, according to Vane-Wright et al.'s (1991) concept of taxic diversity for conservation.

\section{Materials and methods}

\section{Plant material}

This genetic analysis focuses on $54 P$. glaucum L. landraces representing seven populations collected from different bioclimatic sites and regions (continental or seashore) of Tunisia, as described in Table 1.The plant material of this investigation was collected by the end of August and in the first 2 weeks of September 2015 from the three main regions representing the distribution area of this crop species in the North African coastline, namely North East, The Centre East, and the South East of Tunisia.

The collection was made within a circle of $500 \mathrm{~m}$ diameter along the sampling transects, from which 5 to 15 individuals were harvested. Seeds collected from the mature spikes, randomly selected from each landrace, served as plant material for this study. Per landrace accession, 10 seeds were germinated under controlled conditions to avoid open pollination, and their respective leaves were collected to serve as the source of genomic DNA. The bioclimatic and geographic characteristics of the prospected sites in this study are presented in Fig. 1.

\section{Areas description}

The prospected landraces were distributed over three bioclimatological regions of Tunisia. As shown in Fig. 1, the sites S1, S2, and S3 were concentrated in the coastal districts of Cap Bon, in far northeastern Tunisia. The peninsula of Cap Bon, surrounded by the Mediterranean from three sides, has a littoral plain with eastward direction and a 
Table 1 Pearl millet landraces included in this study and their origin

\begin{tabular}{|c|c|c|c|c|c|}
\hline No. & Accession name & Population & Region & Bioclimatic zone & Position \\
\hline 1 & Haouaria 1 & Haouaria & North East & Sub Humid & Coastal \\
\hline 2 & Haouaria 2 & Haouaria & North East & Sub Humid & Coastal \\
\hline 3 & Haouaria 3 & Haouaria & North East & Sub Humid & Coastal \\
\hline 4 & Haouaria 4 & Haouaria & North East & Sub Humid & Coastal \\
\hline 5 & Haouaria 5 & Haouaria & North East & Sub Humid & Coastal \\
\hline 6 & Haouaria 6 & Haouaria & North East & Sub Humid & Coastal \\
\hline 7 & Haouaria 7 & Haouaria & North East & Sub Humid & Coastal \\
\hline 8 & Haouaria 8 & Haouaria & North East & Sub Humid & Coastal \\
\hline 9 & Hammem Jebli 1 & Hammem Jebli & North East & Sub Humid & Coastal \\
\hline 10 & Hammem Jebli 2 & Hammem Jebli & North East & Sub Humid & Coastal \\
\hline 11 & Hammem Jebli 3 & Hammem Jebli & North East & Sub Humid & Coastal \\
\hline 12 & Hammem Jebli 4 & Hammem Jebli & North East & Sub Humid & Coastal \\
\hline 13 & Hammem Jebli 5 & Hammem Jebli & North East & Sub Humid & Coastal \\
\hline 14 & Hammem Jebli 6 & Hammem Jebli & North East & Sub Humid & Coastal \\
\hline 15 & Hammem Jebli 7 & Hammem Jebli & North East & Sub Humid & Coastal \\
\hline 16 & Hammem Jebli 8 & Hammem Jebli & North East & Sub Humid & Coastal \\
\hline 17 & Hammem Laghzez 1 & Hammem Laghzez & North East & Sub Humid & Coastal \\
\hline 18 & Hammem Laghzez 2 & Hammem Laghzez & North East & Sub Humid & Coastal \\
\hline 19 & Hammem Laghzez 3 & Hammem Laghzez & North East & Sub Humid & Coastal \\
\hline 20 & Hammem Laghzez 4 & Hammem Laghzez & North East & Sub Humid & Coastal \\
\hline 21 & Hammem Laghzez 5 & Hammem Laghzez & North East & Sub Humid & Coastal \\
\hline 22 & Hammem Laghzez 6 & Hammem Laghzez & North East & Sub Humid & Coastal \\
\hline 23 & Hammem Laghzez 7 & Hammem Laghzez & North East & Sub Humid & Coastal \\
\hline 24 & Hammem Laghzez 8 & Hammem Laghzez & North East & Sub Humid & Coastal \\
\hline 25 & Hammem Laghzez 9 & Hammem Laghzez & North East & Sub Humid & Coastal \\
\hline 26 & Kairouan 1 & Kairouan & Centre East & Arid Superior & Continenta \\
\hline 27 & Kairouan 2 & Kairouan & Centre East & Arid Superior & Continenta \\
\hline 28 & Kairouan 3 & Kairouan & Centre East & Arid Superior & Continenta \\
\hline 29 & Kairouan 4 & Kairouan & Centre East & Arid Superior & Continenta \\
\hline 30 & Kairouan 5 & Kairouan & Centre East & Arid Superior & Continenta \\
\hline 31 & Kairouan 6 & Kairouan & Centre East & Arid Superior & Continenta \\
\hline 32 & Kairouan 7 & Kairouan & Centre East & Arid Superior & Continenta \\
\hline 33 & Sidi Abdallah 1 & Chebika & Centre East & Arid Superior & Continenta \\
\hline 34 & Sidi Abdallah 2 & Chebika & Centre East & Arid Superior & Continenta \\
\hline 35 & Sidi Abdallah 3 & Chebika & Centre East & Arid Superior & Continenta \\
\hline 36 & Sidi Abdallah 4 & Chebika & Centre East & Arid Superior & Continenta \\
\hline 37 & Sidi Abdallah 5 & Chebika & Centre East & Arid Superior & Continenta \\
\hline 38 & Sidi Abdallah 6 & Chebika & Centre East & Arid Superior & Continenta \\
\hline 39 & Sidi Abdallah 7 & Chebika & Centre East & Arid Superior & Continenta \\
\hline 40 & Sidi Abdallah 8 & Chebika & Centre East & Arid Superior & Continenta \\
\hline 41 & Rejiche 1 & Mahdia & Centre East & Semi Arid Inferior & Coastal \\
\hline 42 & Rejiche 2 & Mahdia & Centre East & Semi Arid Inferior & Coastal \\
\hline 43 & Rejiche 3 & Mahdia & Centre East & Semi Arid Inferior & Coastal \\
\hline 44 & Rejiche 4 & Mahdia & Centre East & Semi Arid Inferior & Coastal \\
\hline 45 & Jorf 1 & Medenine & South East & Arid Inferior & Coastal \\
\hline 46 & Jorf 2 & Medenine & South East & Arid Inferior & Coastal \\
\hline 47 & Jorf 3 & Medenine & South East & Arid Inferior & Coastal \\
\hline
\end{tabular}


Table 1 (continued)

\begin{tabular}{llllll}
\hline No. & Accession name & Population & Region & Bioclimatic zone & Position \\
\hline 48 & Jorf 4 & Medenine & South East & Arid Inferior & Coastal \\
49 & Jorf 5 & Medenine & South East & Arid Inferior & Coastal \\
50 & Jorf 6 & Medenine & South East & Arid Inferior & Coastal \\
51 & Jorf 7 & Medenine & South East & Arid Inferior & Coastal \\
52 & Jorf 8 & Medenine & South East & Arid Inferior & Coastal \\
53 & Jorf 9 & Medenine & South East & Arid Inferior & Coastal \\
54 & Jorf 10 & Medenine & South East & Arid Inferior \\
\hline
\end{tabular}

mountain running across the peninsula in a northeasterly direction to the Tunisian Dorsal. With this unique topography, a fertile soil, and significant rainfall, the Cap Bon has a unique climate, thus stimulating unique genetic resources. The sites S4 and S5 are continental, localized in Kairouan region, $70 \mathrm{~km}$ from the Mediterranean coast. The Kairouan climate is warmer and drier compared to the littoral, as it belongs to the Arid Superior climatic layer. The site S6 is situated in the Presque-isle Mahdia, bordering the eastern shore called "Tunisian Sahel". Jorf presents site S7 in the south-easternmost coast in the arid zone.

\section{DNA extraction and molecular analysis}

Genomic DNA was extracted from leaf samples of 2-weekold seedlings of each accession using the CTAB method (Bowers et al. 1993) with some modifications (Zoghlami et al. 2011). In order to genotype the 54 pearl millet landraces, 18 nuclear SSR markers (Liu et al. 2003; Qi et al. 2004) covering different genomic locations were essayed (Table 2). Each linkage group was represented by at least two loci. A final set of 13 microsatellites covering the seven linkage groups of the species were retained for their consistency in polymorphism, and thereby used in the present analysis. The PCR reactions were performed in a final volume of $20 \mu \mathrm{L}$ consisting of $1 \mu \mathrm{L}$ of DNA (40 ng/mL), 2 $\mu \mathrm{L}$ of $10 \times$ PCR buffer $(200 \mathrm{mM}$ Tris- $\mathrm{HCl} \mathrm{pH} 8.4,500 \mathrm{mM}$ $\mathrm{KCl}$ ), $1.5 \mu \mathrm{L}$ of $2.5 \mathrm{mM}$ dNTPs (promega), $0.25 \mu \mathrm{L}$ of 50 $\mathrm{Mm} \mathrm{Mg} 2+, 2 \mu \mathrm{L}$ of primer $(2.5 \mathrm{mM}), 0.15 \mu \mathrm{L}$ of Invitrogen Taqpolymerase $(1 \mathrm{U} / \mu \mathrm{L})$, and $9.5 \mu \mathrm{L}$ of distilled water. The PCR involved initial denaturation of the template DNA at $94{ }^{\circ} \mathrm{C}$ for $4 \mathrm{~min}$, followed by 35 cycles of denaturation at $94{ }^{\circ} \mathrm{C}$ for $1 \mathrm{~min}$, annealing at 50, 52, 58, or $61^{\circ} \mathrm{C}$ (depending on the melting temperature of each primer) for $1 \mathrm{~min}$, and extension at $72^{\circ} \mathrm{C}$ for $1 \mathrm{~min}$. PCR products were separated on $2.5 \%$ agarose gel.

\section{Data analysis}

The number of alleles $\left(A_{\mathrm{n}}\right)$ and effective number of alleles $\left(A_{\mathrm{e}}\right)$ were calculated using POPGENE 1.32 (Francis et al.
1999). The GENETIX software (Belkhir 1999) was used to calculate the observed heterozygosity $\left(H_{\mathrm{o}}\right)$, the expected heterozygosity $\left(H_{\mathrm{e}}\right)$, the mean number of alleles per locus (MNA), and the inbreeding index (Fis). The degree of polymorphism of each SSR locus was estimated based on the polymorphic information content (PIC) using Cervus 3.0 software (Marshall et al. 1998). The number of genotypes $\left(G_{\mathrm{n}}\right)$ and the number of private alleles $\left(A_{\mathrm{p}}\right)$ were calculated from the matrix genotype using Excel.

To explore the genetic differentiation among the landrace populations, pairwise $F_{\mathrm{ST}}$ values were assessed according to Weir and Cockerham (1984) using GENEPOP (Raymond and Rousset 1995). The gene flow was estimated using the formula: $N_{\mathrm{m}}=1 / 4\left(1-F_{\mathrm{ST}}\right) / F_{\mathrm{ST}}$ (Whitlock and McCauley 1999), using GENETIX (Belkhir 1999).

The illustration of the genetic structure and the relationships between the seven investigated gene pools was obtained by Factorial Correspondence Analysis (FCA) using the function AFC 3D, performed by GENETIX 4.02 computer package (Belkhir 1999). STRUCTURE software version 2.3.3 (Pritchard et al. 2000; Kumar et al. 2009) was used to perform Bayesian clustering following the admixture model with a burn-in of 10.000 and a number of Markov chain Monte Carlo repetitions of 50,000. Evanno's method (Evanno et al. 2005) along with structure harvester (Earl and VonHoldt 2012) were used to infer the number of $K$.

In order to establish conservation priorities, Vane-Wright et al.'s method (1991) was implemented, as described by Delgado et al. (2008), using phylogenetic information inferred from the UPGMA-derived dendrogram and the genetic data assessed at the population level as the number of alleles $\left(A_{\mathrm{n}}\right)$, the private alleles $\left(A_{\mathrm{p}}\right)$, the inbreeding index $(F)$, the observed heterozygosity $\left(H_{\mathrm{o}}\right)$, the expected heterozygosity $\left(H_{\mathrm{e}}\right)$, and the inter-population distance $(D)$. Firstly, phylogenetic importance was deduced as described by Vane-Wright et al. (1991), with some modifications in the study of Delgado et al. (2008), by calculating PTI (taxic diversity index) using two parameters: population grouping (PG), as the number of nodes available in the phylogram and basic population weight (BPW), as the sum of PG 


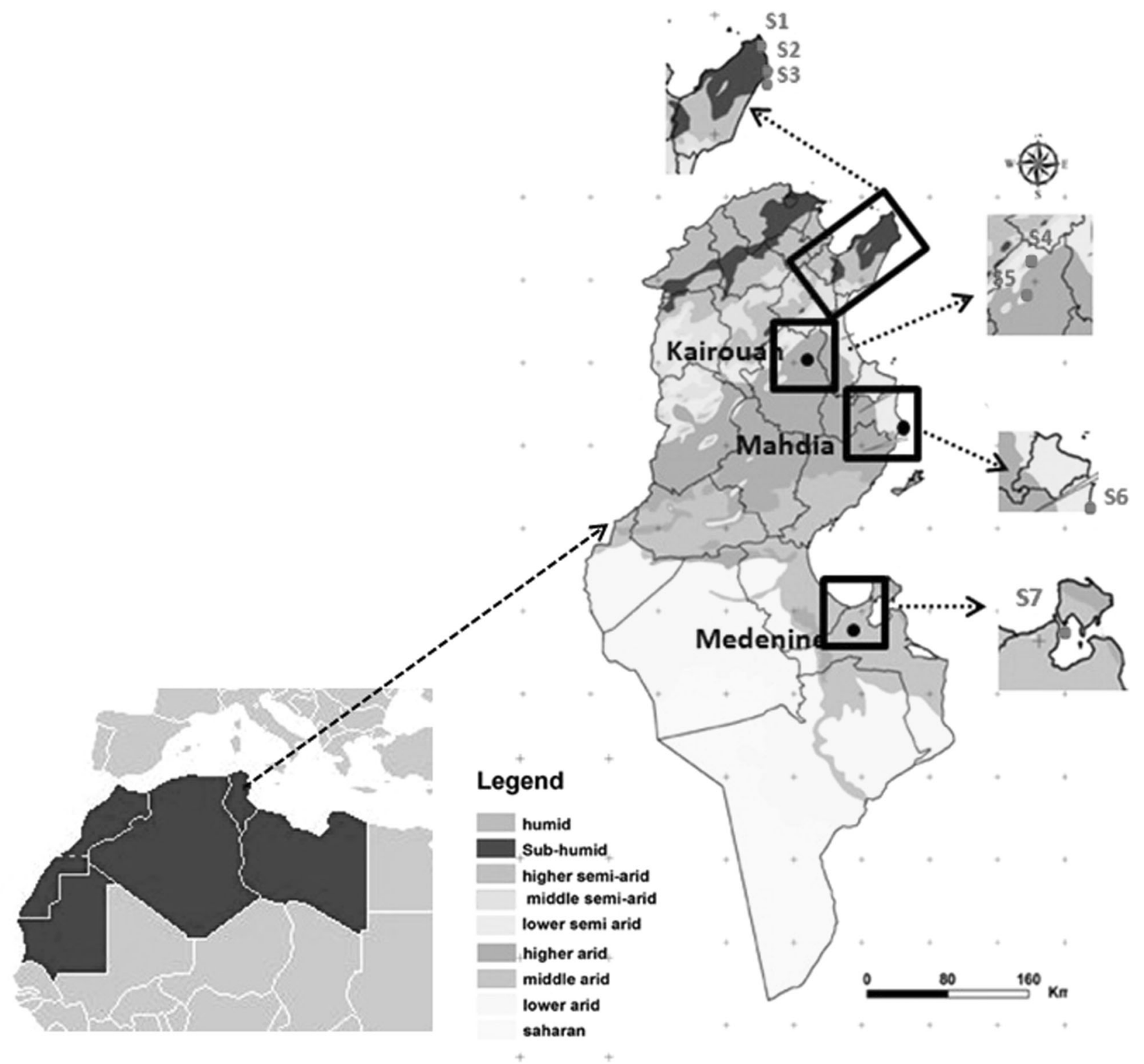

Fig. 1 Location of the studied landraces in the map of Tunisia in the North African region (S1: Haouaria, S2: Hammem Jebli, S3: Hammem Laghzez, S4: Kairouan, S5: Chebika, S6: Mahdia, S7: Medenine)

divided by the PG value of each population. All basic population weights were standardized, as described previously by Delgado et al. (2008) and Chibani et al. (2017).

The genetic data was used to separate the populations displaying the same phylogenetic scores by attributing 1 to the smallest population and the lowest inbreeding index to give them a larger emphasis. Conversely, the allele number $\left(A_{\mathrm{n}}\right)$, private allele number $\left(A_{\mathrm{p}}\right)$, observed heterozygosity $\left(H_{\mathrm{o}}\right)$, expected heterozygosity $\left(H_{\mathrm{e}}\right)$, and genetic distance $(D)$ were standardized by giving 1 to the largest value. The prioritized populations for conservation are the ones exhibiting the highest diversity in terms of the allelic richness and genetic variability. Since phylogenetic information and genetic data were unable to sort the population priorities for conservation when used separately, they were finally integrated in an average sum per population and turned into percentages using the value of the population, with the highest score as a reference value of $100 \%$. The conservation priority is given to the population with the largest percentage.

\section{Results}

\section{Genetic variability among and within populations}

This is the first study that focuses on the molecular analysis of local pearl millet landraces from Tunisia. According to the obtained results, all the 13 used SSR loci were shown to 
Table 2 List of the studied nSSR primers, their characteristics along with their sources, and linkage groups (LG)

\begin{tabular}{|c|c|c|c|c|}
\hline SSR marker & Primer forward $\left(5^{\prime}-3^{\prime}\right)$ & Primer reverse $\left(5^{\prime}-3^{\prime}\right)$ & LG & Source \\
\hline PSMP2273 & AACCCCACCAGTAAGTTGTGCTGC & GATGACGACAAGACCTTCTCTCC & 1 & Qi et al. (2004) \\
\hline PSMP2006 & GACTTATAGTCACTGGGAAAGCTC & GCTTTAATAACTTTGTGCGTATT & 1 & Qi et al. (2004) \\
\hline PSMP2237 & TGGCCTTGGCCTTTCCACGCTT & CAATCAGTCCGTAGTCCACACCCCA & 2 & Qi et al. (2004) \\
\hline PSMP2231 & TGTTGTTGGGAGAGGGTATGAG & CTCTCGCCATTCTTCAAGTTCA & 2 & Qi et al. (2004) \\
\hline PSMP2072 & GAAATCTACACAAGGGTCTCCA & GTACGGCAGAATGACATCTGAA & 2 & Qi et al. (2004) \\
\hline HvM 54 & AACCCAGTAACACCGTCCTG & AGTTCCCTGACCCGATGTC & 2 & Liu et al. (2003) \\
\hline PSMP2056 & ACCTGTAGCTTCAAAATTCAAAAA & ATTCAGTGTGATTTCGATGTTGC & 3 & Qi et al. (2004) \\
\hline PSMP2214 & CGCACAGTACGTGTGAGTGAAG & GATTGAGCAGCAAAAACCAGC & 3 & Qi et al. (2004) \\
\hline PSMP2070 & ACAGAAAAAGAGAGGCACAGGAGA & GCCACTCGATGGAAATGTGAAA & 3 & Qi et al. (2004) \\
\hline PSMP2084 & AATCTAGTGATCTAGTGTGCTTCC & GGTTAGTTTGTTTGAGGCAAATGC & 4 & Qi et al. (2004) \\
\hline PSMP2008 & GATCATGTTGTCATGAATCACC & ACACTACACCTACATACGCTCC & 4 & Qi et al. (2004) \\
\hline PSMP2078 & CATGCCCATGACAGTATCTTAAT & ACTGTTCGGTTCCAAAATACTT & 5 & Qi et al. (2004) \\
\hline PSMP2274 & CACCTAGACTCTACACAATGCAAC & AATATCAAGTGATCCACCTCCCAA & 5 & Qi et al. (2004) \\
\hline PSMP2048 & TGAATTGGGAATAAAGGAGACC & ACGTGTGCCTGCTTTTAGTAAC & 6 & Qi et al. (2004) \\
\hline PSMP2270 & AACCAGAGAAGTACATGGCCCG & CGACGAACAAATTAAGGCTCTC & 6 & Qi et al. (2004) \\
\hline PSMP2248 & TCTGTTTIGTTTGGGTCAGGTCCTTC & CGAATACGTATGGAGAACTGCGCATC & 6 & Qi et al. (2004) \\
\hline PSMP2079 & AGCCGAAGGCTAATCAACAA & GTGGTCAGCAGCAGATGTAA & 7 & Qi et al. (2004) \\
\hline PSMP2074 & AGGACTGTAGGAGTGTGGACAACACA & CCAGACCTACCAGTGAATGAGA & 7 & Qi et al. (2004) \\
\hline
\end{tabular}

Table 3 Characterization of the 13 microsatellite markers used across the seven pearl millet populations from coastal North Africa: number of alleles $\left(A_{\mathrm{n}}\right)$, effective number of alleles $\left(A_{\mathrm{e}}\right)$, number of genotypes $\left(G_{\mathrm{n}}\right)$, polymorphic information content (PIC), observed heterozygosity $\left(H_{\mathrm{o}}\right)$, and the expected heterozygosity $\left(H_{\mathrm{e}}\right)$

\begin{tabular}{lllllll}
\hline Locus & $A_{\mathrm{n}}$ & $G_{\mathrm{n}}$ & $A_{\mathrm{e}}$ & $H_{\mathrm{o}}$ & $H_{\mathrm{e}}$ & PIC \\
\hline PSMP2048 & 9 & 23 & 6.50 & 0.59 & 0.85 & 0.82 \\
PSMP2237 & 8 & 10 & 5.58 & 0.98 & 0.82 & 0.79 \\
PSMP2078 & 10 & 12 & 3.81 & 0.44 & 0.74 & 0.69 \\
PSMP2056 & 7 & 17 & 4.91 & 0.64 & 0.80 & 0.76 \\
PSMP2014 & 6 & 9 & 3.36 & 0.87 & 0.70 & 0.64 \\
PSMP2273 & 5 & 12 & 4.34 & 0.59 & 0.77 & 0.73 \\
PSMP2231 & 8 & 13 & 4.74 & 0.61 & 0.79 & 0.76 \\
PSMP2248 & 8 & 13 & 4.30 & 0.81 & 0.77 & 0.73 \\
HVM54 & 8 & 18 & 5.46 & 0.50 & 0.82 & 0.79 \\
PSMP2274 & 9 & 19 & 6.19 & 0.66 & 0.84 & 0.81 \\
PSMP2070 & 8 & 15 & 5.34 & 0.92 & 0.82 & 0.78 \\
PSMP2006 & 7 & 17 & 5.19 & 0.81 & 0.81 & 0.77 \\
PSMP2072 & 9 & 18 & 5.99 & 0.64 & 0.84 & 0.81 \\
Means & $7.85 \pm$ & $15.08 \pm$ & $5.05 \pm$ & $0.70 \pm$ & $0.80 \pm$ & $0.76 \pm$ \\
& 1.34 & 4.01 & 0.93 & 0.16 & 0.04 & 0.05 \\
\hline
\end{tabular}

be polymorphic in the analyzed sample (Table 3). A total of 102 alleles were detected with a mean of 7.85 alleles per locus. The number of alleles ranged from 5 (PSMP2273) to 10 (PSMP2078). Among the total 102 detected alleles, 65.71 alleles were shown effective with a mean of 5.05 effective alleles per locus. The highest level of effective allele was recorded for the locus PSMP2048 (6.50), while the locus PSMP2014 presented the lowest effective allele number (3.36).

In addition to the allelic richness, allelic combinations are an important genetic parameter showing the genetic diversity of a given species. The 102 detected alleles combined into 196 genotypes calculated from the matrix genotype with an average of 15.08 genotypes per locus.

The loci PSMP2048 and PSMP2274 had the highest number of detected genotypes, respectively 23 and 19 . To highlight the most informative SSR molecular markers among the investigated set of nSSR loci, the polymorphic information content (PIC) was calculated across the total studied sample of pear millet landraces. Based on this parameter, all the loci were shown informative with a mean PIC value of 0.76 . The most informative loci were PSMP2048 (PIC $=0.82$ ), PSMP2274 (PIC $=0.81$ ), and PSMP2072 (PIC $=0.81$ ), while the loci PSMP2014 showed the lowest polymorphic information content (0.64).

The observed heterozygosity $\left(H_{\mathrm{o}}\right)$ for the total studied sample varied according to the used SSR loci from 0.44 (PSMP2078) to 0.98 (PSMP2237), with a mean value of 0.70 . Similarly a high gene diversity $H_{\mathrm{e}}$ was recorded varying from 0.70 (PSMP2014) to 0.85 (PSMP2048), with a mean value of 0.80 was observed. The allelic richness detected in this germplasm could be relevant to their wild character.

Comparable levels of genetic diversity were observed among the seven studied populations (Table 4). Among the 102 detected alleles, the highest number of alleles (69) was observed in Kairouan originating landraces, while the 
Table 4 Genetic variability within North African populations of pearl millet landraces present in coastline: allele number $\left(A_{\mathrm{n}}\right)$; private allele number $\left(A_{\mathrm{p}}\right)$, mean number of alleles per locus (MNA), observed heterozygosity $\left(H_{\mathrm{o}}\right)$, expected heterozygosity $\left(H_{\mathrm{e}}\right)$, and inbreeding index $(F)$

\begin{tabular}{lllllllll}
\hline Number code & Population name & Size & $A_{\mathrm{n}}$ & $A_{\mathrm{p}}$ & MNA & $H_{\mathrm{o}}$ & $H_{\mathrm{e}}$ & $F$ \\
\hline 1 & Haouaria & 8 & 59 & 2 & 4.54 & $0.68 \pm 0.31$ & $0.70 \pm 0.18$ & 0.031 \\
2 & Hammem Jebli & 8 & 67 & 1 & 5.15 & $0.66 \pm 0.29$ & $0.75 \pm 0.11$ & 0.119 \\
3 & Hammem Laghzaz & 9 & 67 & 5 & 5.15 & $0.73 \pm 0.30$ & $0.76 \pm 0.07$ & 0.041 \\
4 & Kairouan & 7 & 69 & 4 & 5.31 & $0.73 \pm 0.27$ & $0.81 \pm 0.05$ & 0.112 \\
5 & Chebika & 8 & 61 & 3 & 4.69 & $0.72 \pm 0.32$ & $0.77 \pm 0.05$ & 0.069 \\
6 & Mahdia & 4 & 51 & 2 & 3.92 & $0.69 \pm 0.27$ & $0.77 \pm 0.07$ & 0.111 \\
7 & Medenine & 10 & 68 & 4 & 5.23 & $0.69 \pm 0.24$ & $0.74 \pm 0.12$ & 0.073 \\
Means & & & 63.14 & 3 & $4.86 \pm 0.50$ & $0.70 \pm 0.02$ & $0.76 \pm 0.03$ & \\
\hline
\end{tabular}

\begin{tabular}{llllllll}
\hline & Haouaria & $\begin{array}{l}\text { Hammem } \\
\text { Jebli }\end{array}$ & $\begin{array}{l}\text { Hammem } \\
\text { Laghzaz }\end{array}$ & Kairouan & Chebika & Mahdia & Medenine \\
\hline Haouaria & - & 2.93 & 3.45 & 3.64 & 3.86 & 5.07 & 2.23 \\
Hammem Jebli & $0.0785^{* *}$ & - & 6.41 & 3.64 & 3.33 & 3.12 & 3.23 \\
Hammem & $0.0676^{* *}$ & $0.0375 * *$ & - & 4.26 & 3.60 & 2.31 & 4.09 \\
Laghzaz & & & & & & & \\
Kairouan & $0.0642 * *$ & $0.0643 * *$ & $0.0555^{* *}$ & - & 65.79 & 999999.00 & 3.17 \\
Chebika & $0.0608^{* *}$ & $0.0699 * *$ & $0.0650^{* *}$ & $0.0038^{\mathrm{ns}}$ & - & 10.92 & 2.95 \\
Mahdia & $0.0470^{* *}$ & $0.0741^{* *}$ & $0.0976^{* *}$ & $-0.0030^{\mathrm{ns}}$ & $0.0224 * *$ & - & 2.02 \\
Medenine & $0.1007 * *$ & $0.0718^{* *}$ & $0.0577 * *$ & $0.0730^{* *}$ & $0.0781^{* *}$ & $0.1102 * *$ & - \\
\hline
\end{tabular}

Table 5 Pairwise $F_{\mathrm{ST}}$ values among the studied populations (in the lower triangle), and the $N_{\text {m }}$ values (above the diagonal)

$* * P<0.01$

ns: not significant

lowest allele number (51) was observed for Mahdia population. The mean allele number per population (MNA) varied from 3.92 for population Mahdia to 5.31 for Kairouan population. The observed heterozygosity $\left(H_{\mathrm{o}}\right)$ of the studied populations are high and varied from 0.66 (population of Hammem Jebli) to 0.73 (Hammem Laghzaz). High gene diversities $\left(H_{\mathrm{e}}\right)$ were observed for all the investigated landrace germplasms with low differences among them. Kairouan population highlighted the highest gene diversity level $\left(H_{\mathrm{e}}=0.81\right)$, while Haouaria pearl millet landraces showed the lowest $H_{\mathrm{e}}$ level $\left(H_{\mathrm{e}}=0.70\right)$ among the studied populations. In addition to the shared alleles, the investigated populations were characterized by some private alleles, $A_{\mathrm{p}}$, which ranged from 1 for Hammem Jebli population to 5 specific alleles for Hammem Laghzaz germplasm, with a mean value of 3 specific alleles per population. For all populations, the inbreeding index was positive, underlining a high excess of heterozygosity.

\section{Genetic differentiation and gene flow analyses}

Low but significant differentiations among the majority of the studied populations were observed. Except for the pairwise $F_{\mathrm{st}} \mathrm{s}$ between the three populations of the centre east of Tunisia which were shown to be nonsignificant, all pairwise $F_{\mathrm{ST}}$ values are highly significant for $P<0.01$. An average pairwise $F_{\mathrm{ST}}$ value of 0.062 was observed (Table
5). The lowest genetic differentiation level was recorded between Kairouan and Mahdia gene pools, with a pairwise $F_{\text {ST }}$ value of $-0.0030^{\text {ns }}$. However the highest genetic differentiation was observed between Medenine and Mahdia populations $\left(F_{\mathrm{ST}}=0.1102 * *\right)$. This was confirmed by the obtained pairwise gene flow values $\left(N_{\mathrm{m}}\right)$. The lowest $N_{\mathrm{m}}$ pairwise value was recorded between Medenine and Mahdia populations $\left(N_{\mathrm{m}}=2.02\right)$, while the highest levels were observed among Mahdia-Kairouan (999999.00). Similarly, a high $N_{\mathrm{m}}$ value was reported between Chebika-Kairouan (65.79) and Chebika-Mahdia (10.92) germplasms.

\section{Pattern of genetic structure}

Genetic relationships between the seven pearl millet landrace populations were visualized using 3D Multivariate Factorial Correspondence Analysis. The plot showed the classification of the studied populations in three groups A, B, and C (Fig. 2). North East populations (Haouaria, Hammem Jebli, and Hammem Laghzez) were clustered in group A, whereas centre east pools (Kairouan, Chebika, and Mahdia) in group B. Group C consisted of the population Medenine representative of the south pearl millet cultivation zone. Based on this analysis, a clear genetic structure according to geographical origin of the investigated landrace populations was observed. 


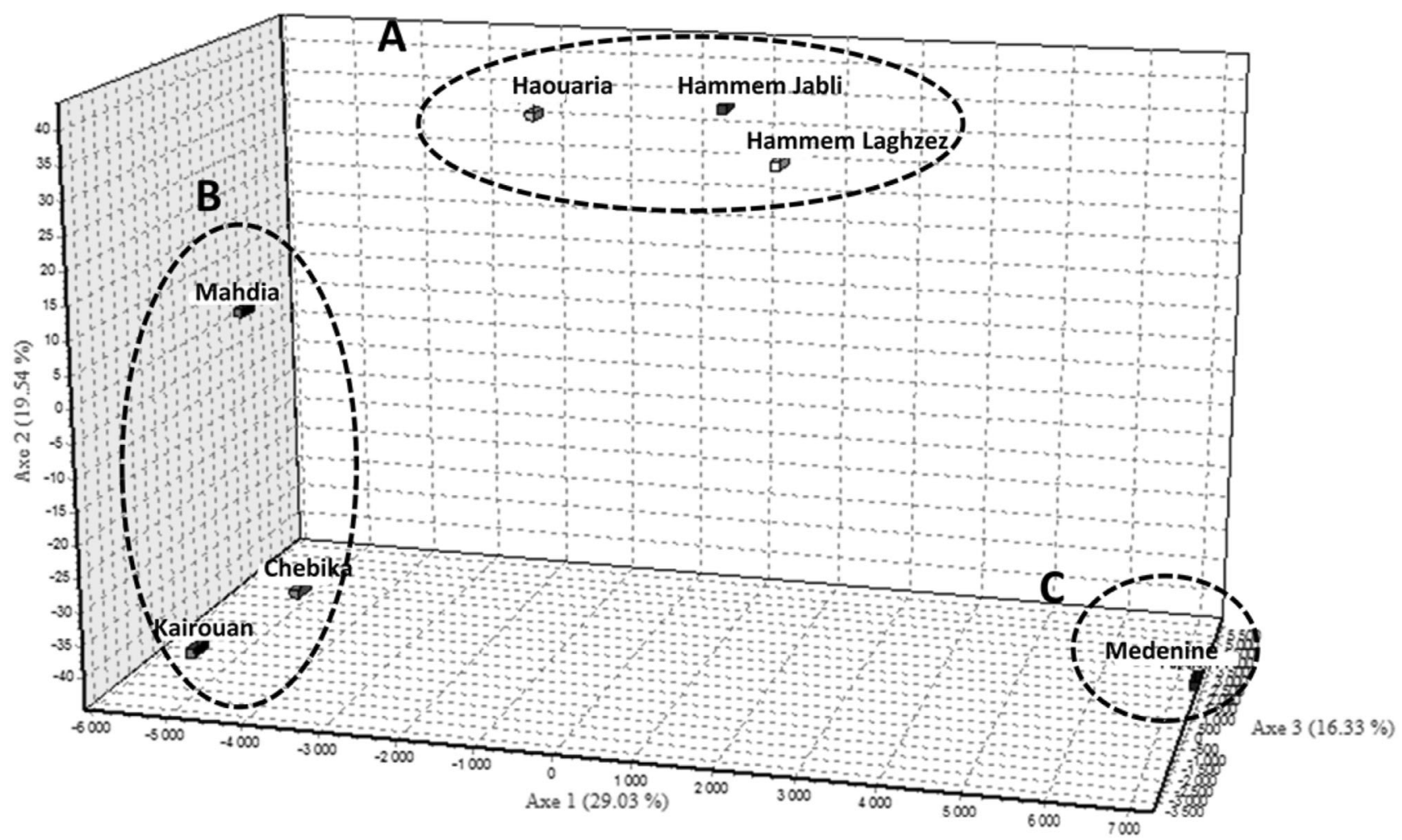

Fig. 2 Tridimensional FCA showing the spatial representation of the seven pearl millet landrace populations

This finding is confirmed by Bayesian cluster analysis and the delta $K$ plot, which showed an apparent admixture among the studied populations with low structure pattern observed among the accessions of the different regions. Bayesian analysis revealed that the number of populations can be assumed to be two $(K=2)$ (Fig. 3a, b).

\section{Conservation priorities}

The Vane-Wright et al. method (1991) was applied with the aim of setting up suitable conservation strategies for pearl millet landrace populations from Tunisia based upon the priority scores calculated from phylogenetic and genetic criteria, as previously documented in Delgado et al. (2008) and Chibani et al. (2017).

Based upon phylogenetic criteria calculated from the UPGMA-derived dendrogram (Fig. 4) and PTI scores (Table 6), populations 1 "Haouaria" and 7 "Medenine" were ranked as the highest priorities for conservation. Population "Medenine" was the most basal in the dendrogram of Fig. 4, at only one node from the root, whereas populations "Haouaria" along with population "Medenine" presented the highest PTI scores. Nevertheless, since the remaining populations appeared after at least one bifurcation and have had similar PTI values ( 0.666 for populations " 2,3 , and 6", and 0.500 for populations " 4 and 5"), the phylogenetic criterion was unable to separate the terminal populations exhibiting identical phylogenetic importance.
On the other hand, when based upon genetic parameters, allele number $\left(A_{\mathrm{n}}\right)$, private allele number $\left(A_{\mathrm{p}}\right)$, expected $\left(H_{\mathrm{e}}\right)$ and observed heterozygosities $\left(H_{\mathrm{o}}\right)$, populations 3 and 4 were identified as the most relevant for conservation. However, when based on inbreeding index $(F)$ and genetic distance $(D)$ values (shown in supplementary material 1 ), highest conservation scores were attributed to population 1 and 7.

Hence, as phylogenetic and genetic data were not conclusive to deduce conservation priorities when used separately, both data were integrated according to Vane-Wright et al. (1991) and as previously documented in Delgado et al. (2008) and Chibani et al. (2017).

As revealed from the summary of the calculated priorities (Table 6), population 7 "Medenine", 3 "Hammem Laghzez", and 1 "Haouaria" have, respectively, the highest priority scores $(100 \%, 99.90 \%$, and $98.41 \%)$. The conservation of the latter populations is therefore compulsory. Population 6 "Mahdia" should be included in the conservation program as being with the smallest sampling size.

\section{Discussion}

Since the Convention on Biological Diversity (CBD 1992), the world's intention was greatly concentrated on saving the natural world heritage from drastic genetic erosion, mainly provoked by a strong anthropological intervention. The 


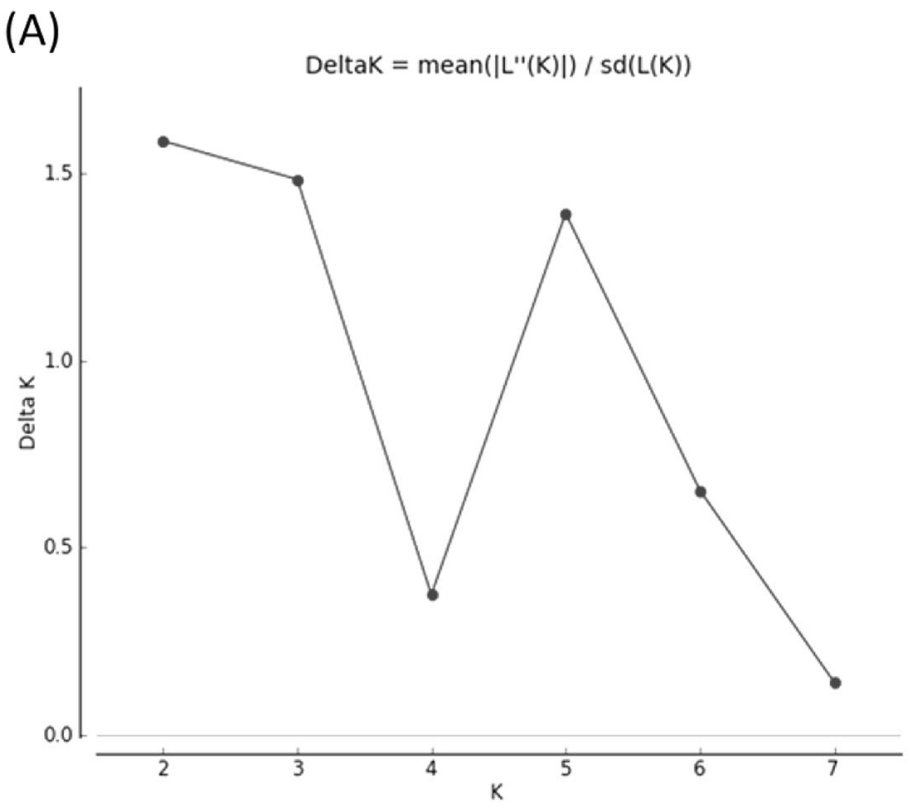

(B)

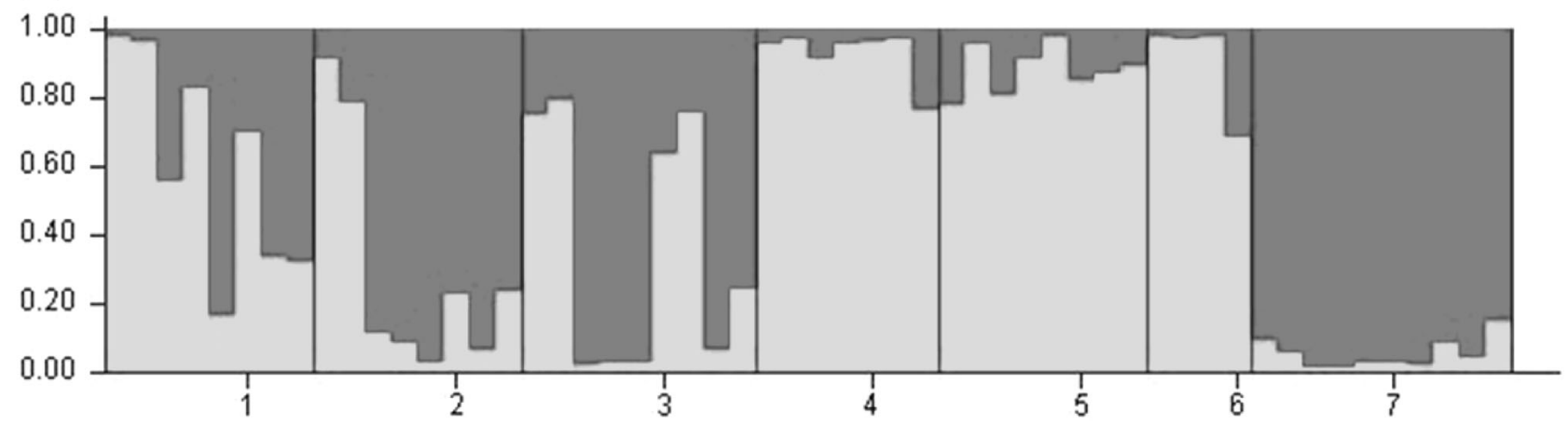

Fig. 3 Bayesian clustering for the seven pearl millet landrace populations representing coastal North African germplasm. a Plot of delta $(k)$ with $k$ =1-7 obtained through Structure harvester ver. 0.6. application (Earl and Vonholdt 2012), showing highest value at $2(K=2)$; b Structure bar plot (see the name of the population in Table 1)

conservation of these endangered biological resources can be performed through stringent recommendations depending mostly on prioritizing the species that are the most threatened by extinction. Fortunately, in several developing countries, some indigenous farming householders have contributed to saving the agro-biodiversity by reproducing traditional cultivars under harsh conditions. These old seeds stored over domestication time continued to evolve and adapt through diverse environmental conditions, making them a precious gene reservoir useful in future improvement programs. To date, the monitoring of the genetic diversity and population differentiation of these local resources remains a valuable need to establish appropriate conservation strategies.

Generally, coastal North African pearl millet is growing as scattered populations by marginal-holder farming systems in order to meet their own needs in terms of food security and economic subsistence. Unfortunately, these last decades have seen the cultivation area of this staple crop decreasing due to competition from other cereals, despite its various nutritional virtues. Till now, there are no studies assessing the genetic diversity in North African pearl $P$. glaucum germplasm cultivated in Mediterranean coastlines, which hinder a reliable establishment of the adequate preservation measurements.

\section{Genetic variability among and within populations}

It has been substantiated that microsatellites combined to the suitable statistics are an efficient molecular tool to decipher the genetic diversity of several crops. In pearl millet, various diversity evaluation analyses employed SSRs as molecular markers to enable consistent variabilitybased conclusions for conservation and management of this germplasm (Mariac et al. 2006; Oumar et al. 2008; Stich et al. 2010 and Bashir et al. 2015). 
In our case, this molecular study based on nuclear SSR markers highlighted a high genetic polymorphism for landrace germplasm of the species $P$. glaucum $\mathrm{L}$. in coastal North Africa. This corroborates a previous report concerning Tunisian pearl millet landraces based on morphological traits (Loumerem et al. 2008), which revealed considerable phenotypic variation for the studied germplasm that was collected exclusively from arid zones. Based on our results, the obtained level of genetic diversity $(0.80)$ and observed heterozygosity $(0.70)$ of the investigated landraces are comparable to the level of gene diversity $\left(H_{\mathrm{e}}=0.77\right)$ and the observed heterozygosity $\left(H_{0}=0.81\right)$ recorded for Sudanese pearl millet landraces (Bashir et al. 2015). A comparable level of the mean number of rare alleles (3.5) was also reported by the last authors for Sudanese land-

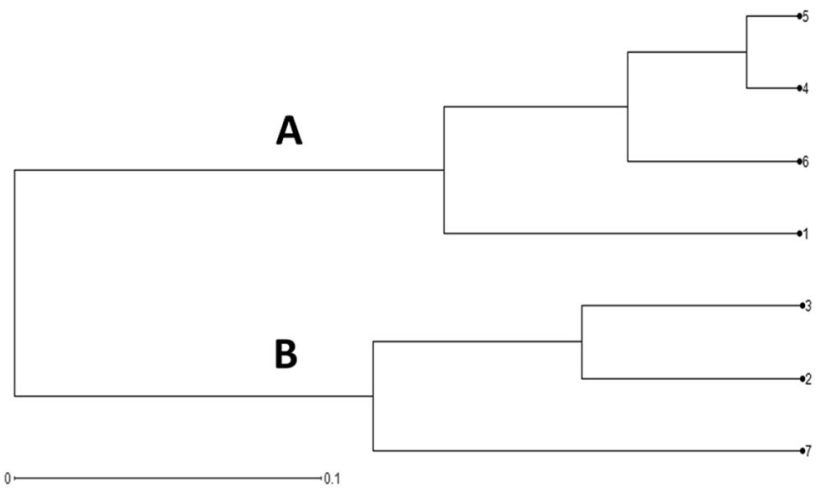

Fig. 4 The UPGMA-derived dendrogram used for calculating the phylogenetic importance of the investigated pearl millet landrace populations, according to the Vane-Wright et al. (1991) concept. The quantified parameters were: the population grouping (PG), which is the number of nodes present in the dendrogram, the basic population weight (BPW), which is the sum of all PG values between the PGn node values that group populations or branches (see Table 1 for population names) races, although they investigated a set of 214 landraces originated from different geographical regions of Sudan and 11 accessions from West Africa.

Lower gene diversity level was observed by Stich et al. (2010) concerning pearl millet germplasms from West and Central Africa $\left(H_{\mathrm{e}}=0.74\right)$ through the larger sampling size (145 inbred lines), which suggests that landraces incorporate more genetic diversity than inbreds. This finding was corroborated with maize (Zea mays L.), an allogamous species, when 193 landraces and 260 inbreds were compared in terms of allelic richness and gene diversity using microsatellites (Liu et al. 2003). The latter reported that maize inbred lines capture only $78 \%$ as many alleles as landraces. This is to say that the crop's wild relatives can definitely provide more genetic information than inbreds, and future breeding programs can benefit from this genetic variability.

Coastal North African locally adapted germplasm of $P$. glaucum L. also showed higher gene diversity than that reported for a world collection of cultivated pearl millet originating from the whole distribution area of the crop in Africa and Asia (0.58) and wild groups (0.73) (Oumar et al. 2008). Additionally, investigation by Mariac et al. 2006, which involved 421 cultivated accessions and 46 wild samples in Niger showed an average gene diversity of 0.49 and 0.67, respectively. All these outcomes demonstrate the importance of North African pearl millet germplasm present on the shores of the Mediterranean sea as valuable genetic resources useful for both $P$. glaucum L. species and the grass family in this region, suggesting immediate preservation procedures for these resources for future breeding programs.

In our case, 21 private alleles out of the 102 were detected and $66.66 \%$ of the assessed rare alleles were recorded in the littoral zone, which could be sorely linked to

Table 6 Application of the Vane-Wright et al. (1991) approach using demographic, genetic, and phylogenetic criteria for attributing conservation priority scores for the studied Pennisetum glaucum L. landrace populations from coastal North African region

\begin{tabular}{|c|c|c|c|c|c|c|c|c|c|c|c|c|c|c|}
\hline \multirow[b]{2}{*}{ Population } & \multicolumn{7}{|c|}{ Standarized genetic data } & \multicolumn{4}{|c|}{ Phylogentic data } & \multirow[t]{2}{*}{ PTI st } & \multirow[t]{2}{*}{ Summary } & \multirow[t]{2}{*}{ Priority } \\
\hline & Size st & $A_{\mathrm{n}} \mathrm{st}$ & $A_{\mathrm{p}} \mathrm{st}$ & $H_{\mathrm{o}} \mathrm{st}$ & $H_{\mathrm{e}} \mathrm{st}$ & $F$ st & $D$ st & PG & BTW & $E$ & PTI \% & & & \\
\hline Haouaria & 0.5 & 0.855 & 0.4 & 0.939 & 0.868 & 1 & 0.816 & 2 & 10.5 & 2 & 20 & 1 & 6.378 & $98.41 \%$ \\
\hline Hammem Jebli & 0.5 & 0.971 & 0.2 & 0.913 & 0.923 & 0.26 & 0.705 & 3 & 7 & 1.33 & 13.33 & 0.666 & 5.138 & $79.27 \%$ \\
\hline Hammem Laghzaz & 0.444 & 0.971 & 1 & 1 & 0.933 & 0.756 & 0.705 & 3 & 7 & 1.33 & 13.33 & 0.666 & 6.475 & $99.90 \%$ \\
\hline Kairouan & 0.751 & 1 & 0.8 & 0.998 & 1 & 0.276 & 0.126 & 4 & 5.25 & 1 & 10 & 0.5 & 5.451 & $84.10 \%$ \\
\hline Chebika & 0.5 & 0.884 & 0.6 & 0.994 & 0.954 & 0.449 & 0.126 & 4 & 5.25 & 1 & 10 & 0.5 & 5.007 & $77.25 \%$ \\
\hline Mahdia & 1 & 0.739 & 0.4 & 0.953 & 0.946 & 0.279 & 0.394 & 3 & 7 & 1.33 & 13.33 & 0.666 & 5.377 & $82.96 \%$ \\
\hline Medenine & 0.4 & 0.985 & 0.8 & 0.953 & 0.919 & 0.424 & 1 & 2 & 10.5 & 2 & 20 & 1 & 6.481 & $100 \%$ \\
\hline Total & & & & & & & & 21 & 52.5 & 10 & & & & \\
\hline
\end{tabular}

$\%$ PTI taxic diversity index: the contribution of each population in the total diversity (for example for population $1: \%$ PTI $=E \times 100 / E$ )

$A_{\mathrm{n}}$ allele number, $A_{\mathrm{p}}$ private allele number, $H_{\mathrm{o}}$ observed heterozygosity, $H_{\mathrm{e}}$ expected heterozygosity, $F$ inbreeding index, $D$ genetic distance, $s t$ standardize, $P G$ population grouping, $B P W$ basic population weight, $E$ the standardization of BPW between smaller (minimum) values 
growth conditions-associated traits (Huenneke 1991; Torres et al. 2003). This finding is indeed, in accordance with the one reported by Loumerem et al. (2008). The author investigated $P$. glaucum landraces cultivated in the Tunisian arid zone from the continental and the coastal areas using morphological descriptors and inferred that the most interesting accessions in terms of stem production and high grain yield originated from "Zarzis" and "Dakhla", both situated in the south-easternmost coast. Therefore, higher attention should be attributed to the genetic resources cultivated in the Mediterranean littoral.

\section{Population structure analysis}

The understanding of how populations are shaped throughout the microevolutionary processes is primordial to set up conservation recommendations. SSRs markers are widely used to decipher genetic differentiation and relationships.

In the current study, pairwise $F_{\mathrm{ST}}$ and gene flow $\left(N_{\mathrm{m}}\right)$ values were calculated among the coastal North African pearl millet landrace populations. Low but significant values of $F_{\mathrm{ST}}$ were recorded with an average of 0.062 . Lower genetic differentiation levels were reported between Sudanese pearl millet landraces, based on SSR molecular markers with pairwise $F_{\mathrm{ST}}$ comparisons varying from 0.004 to 0.037 among the different geographical regions (Bashir et al. 2015). Similar genetic differentiation means were detected within the Lake Chad Basin populations (0.057) (Naino Jika et al. 2017). Higher genetic differentiation averages (0.14) were observed between wild and cultivated groups of pearl millet germplasms (Oumar et al. 2008).

Low genetic differentiation values were accompanied by considerable gene flow levels, which are confirmed by previous investigations concerning pearl millet landraces (Bashir et al. 2015) and other crop species such as barley (Ben Romdhane et al. 2017). This finding is expected especially for a highly allogamous species like $P$. glaucum $\mathrm{L}$, which present an out-crossing rate higher than $85 \%$. This is decreased by the overlapping between the early and late flowering pearl millet landraces within the growing regions (Bashir et al. 2015).

Conversely, AFC-3D (Fig. 2) and Bayesian cluster analysis (Fig. 3b) exhibited a clear genetic pattern when the geographic origin was taken into account. This plot has indeed showed that the shaping of the genetic structure of the Tunisian seven pearl millet landraces occurred on the basis of their main three originating geographical regions (Fig. 1). Moreover, the AFC-3D has clearly displayed a high differentiation of the coastal populations as "Medenine", the populations of the northeastern Tunisia, and "Mahdia" while the continental ones namely "Kairouan" and "Chebika" are agglomerated at the bottom of the plot.
This genetic distinctiveness could be related to the high number of unique alleles incorporated in the coastal germplasm. Besides, the remarkable geographic pattern of the population structure and the genetic variation among the investigated populations are likely defined by the different agricultural practices applied by these marginal smallholders farmers. Additionally, the soil water availability along with the edaphic features are major factors with an immediate incidence on the modeling of the population genetic structure. This could be similar to the finding reported by Naino Jika et al. (2017), showing the existence of a genetic structure of pearl millet mainly associated with ethno-linguistic diversity in the western side of the Lake Chad. Based on SNP molecular markers comparative analysis of global accessions and Senegalese landraces, geographic structure among countries was only showed in the global accessions. The structure observed within Senegalese germplasm did not present a geographic pattern. However, clear population structure was observed between global accessions and Senegalese landraces, and the geographic structure was observed among countries, but not within Senegal (Hu et al. 2015). This is to say that the differentiation among populations according to the geographic distribution could be explained by the climate control or the different cultural traditions and practices, or inter-ethnic contacts, or economic pressures.

\section{Genetic and phylogenetic data to attribute conservation scores}

To undertake the adequate conservation measurements, decisions have to be premised on robust criteria. Thus, demographic, genetic, and phylogenetic informations were considered independently, then integratively at the population level to attribute conservation scores using the VaneWright et al. (1991) concept of taxic diversity (Table 6). This approach has proven its efficiency when applied on a great diversity of species, genera, or families (May 1990; Vane-Wright et al. 1991; Williams et al. 1991; Crozier 1992; Santos del Prado 1996; and Fjeldsa 2000), but also when used at intraspecific level (Faith 1992; Arita and Santos del Prado 1999; Moritz and Faith 1998; Petit et al. 1998; Eguiarte et al. 1999; Delgado et al. 2008).

In the current study, once the phylogenetic and genetic data were standardized separately, different and inconclusive conservation inferences were obtained. This outcome is in accordance with those documented in Delgado et al. (2008) and Chibani et al. (2017). The limitation of the phylogenetic data is indeed due to the heterogeneous difference levels among the terminal and basal populations (Crozier 1992). In our case, the population 7 "Medenine" is the most basal population of the dendrogram and could be considered as the output of the analysis (Fig. 4). This status 
was consolidated by the calculated genetic distances according to Nei (1978), which clearly showed that population 7 "Medenine" was the most distinguished, by exhibiting the highest average genetic distance (0.301). The latter, is indeed the most distant, genetically speaking, as the largest genetic dissimilarity was recorded between the populations "Mahdia and "Medenine" (0.514) (supplementary material 1). Population 1 "Haouaria" and population 7 "Medenine" displayed the highest taxic diversity and deserve, thereby, the highest intention when conservation strategies are set up. Notwithstanding, this approach denigrates terminal populations (with equal PTI) with considerable genetic variation or allelic uniqueness (expressed by private alleles) (Delgado et al. 2008), hindering the best management of these precious resources. Hence, to overcome this problem, other indices were employed with the aim of sorting the remaining populations exhibiting identical PTI. Demographic parameter emphasizes the smallest populations (in our case population 6 "Mahdia), as they are the most threatened by the extinction (Lande 1988; Ellstrand and Elam 1993; Delgado et al. 2008), and therefore given the highest score (1). Genetic data are prominent criteria to select the highly prioritized populations for conservation as long as all the consideration is steered to the populations with the greatest level of genetic variation (Delgado et al. 2008). In our case, according to the standardized genetic parameters (the allele number $\left(A_{\mathrm{n}}\right)$, private allele number $\left(A_{\mathrm{p}}\right)$, observed heterozygosity $\left(H_{\mathrm{o}}\right)$, expected heterozygosity $\left(H_{\mathrm{e}}\right)$, and genetic distance $\left.(D)\right)$, population 3 "Hammem Laghzez" had the greatest priority score. As documented in May (1990), although genetic data could be useful for setting up the suitable preservation priorities, their integration with other criteria should not be excluded. According to the aforementioned findings, the standardization and the sum of all indices allowed the attribution of highest priority scores to populations "Medenine", "Hammem Laghzaz", and "Haouaria" with population "Mahdia" as being the smallest one. The aforesaid populations are representatives of the three main pearl millet growing regions in Tunisia and restricted to the coastal zone, which makes them highly interesting not only at the national level, but also for the North African region.

\section{Conservation recommendations}

Traditional landraces often draw the attention of the research community, as they incorporate a tremendous range of useful genes for engendering varieties with enhanced adaptability and productivity. Their increasing extinction is seen as a huge loss for the global genetic heritage and a threat to the future food security. Thus, the preservation of this precious agrobiodiversity warrants being involved in both on-farm and ex situ conservation plans.
The wild relatives of the domesticated crops are basically conserved ex situ into gene banks (Holubec et al. 2010). Besides, the on-farm preservation strategy offers a fair option to safeguard this genetic wealth either in its initial habitat by maintaining the concerned landraces under cultivation within their farming systems (Holubec et al. 2010) or in in situ living collections by propagating them in protected areas (Volis et al. 2010). Nevertheless, the latter method could induce loss of the adaptive potential of the conserved landraces.

In our case, the inferred outcomes from genetic, demographic, and phylogenetic data lead to a rational preservation plan involving an ex situ conservation strategy by selecting "Haouaria" and "Medenine" populations of highly phylogenetic importance with "Hammem Laghzez" population possessing high number of private alleles and also population "Mahdia", according to the demographic considerations. These latter are luckily the representatives of the coastal zone of North Africa and should therefore be preserved in national seed-banks.

Conversely, returning the landraces from the seed banks to the farming systems or managing field gene banks remains a fastidious alternative in Tunisia due to its highly consequent costs and the unavailability of practical logistics. Moreover, the rural areas have very low literacy rates making the on-farm conservation plan complicated.

National efforts have to be undertaken to maintain such genetic resources by seriously supporting these marginal farmers financially to keep on the propagation of their traditional seeds.

\section{Conclusions}

To summarize, the current report investigates at the molecular level the few remaining pearl millet old landraces that have escaped from genetic extinction and are fortunately still cultivated in coastal North African marginal areas. The findings related to the genetic variation among and within the investigated pearl millet germplasms attest to the high amount of the genetic richness incorporated in these traditional cultivars and thereby should be involved in, firstly, ex situ conservation plan. Furthermore, governmental efforts need to raise the awareness in the agriculture community concerning the importance of these crop wild relatives and provide incentives to the farmers with small land holdings to keep cultivating their own cultivars.

\section{Data archiving}

Data available from the Dryad Digital Repository: https:// doi.org/10.5061/dryad.gp350rt. 
Acknowledgements The authors are grateful to the Tunisian Ministry of Higher Education and Scientific Research for financial support. We also thank Professor Peter Felker, Casa de Mesquite, Hollister, California, USA, for the language editing.

\section{Compliance with ethical standards}

Conflict of interest The authors declare that they have no conflict of interest.

\section{References}

Arita H, Santos del Prado K (1999) Conservation biology of nectarfeeding bats in Mexico. J Mammal 80:31-41

Bashir EMA, Abdelbagi MA, Adam MA, El Tahir IM, Albrecht EM, Heiko KP, Bettina IG (2015) Genetic diversity of Sudanese Pearl millet (Pennisetum glaucum (L.) R. Br.) landraces as revealed by SSR markers, and relationship between genetic and agromorphological. Divers Genet Resour Crop Evol 62:579-591

Belkhir K (1999) GENETIX version 4.02: a Windows program for population genetic analysis. Laboratoire genome, populations, interactions. UPR 9060. CNRS, Univ,Montpellier, France

Ben Romdhane M, Riahi L, Selmi A, Jardak R, Bouajila A, Ghorbel A, Zoghlami N (2017) Low genetic differentiation and evidence of gene flow among barley landrace populations in Tunisia. Crop Sci 57:1-9

Bhattacharjee R, Bramel J, Hash T, Kolesnikova-Allen A, Khairwal S (2002) Assessment of genetic diversity within and between Pearl millet landraces. Theor Appl Genet 105:666-73

Bowers JE, Bandmann EB, Meredith CP (1993) DNA fingerprinting and characterization of some wine grape cultivars. Am J Enology Vitic 44:266-274

CBD (Convention on Biological Diversity) (1992) CBD convention text. http://www.cbd.int/convention/text/

Chakauya E (2002) Genetic diversity assessment of sorghum [Sorghum bicolor (L.) Moench] and Pearl millet (Pennisetum glaucum L. R. Br.) landraces collected from Zimbabwe's communal areas, based on microsatellites and isozymes. M.S. Thesis, University of Zimbabwe

Chibani F, Skouri-Gargouri H, Ben Salem A, Ghorbel A, Zoghlami N (2017) Using genetic structure data and phylogenetic criteria in attributing prioritization scores for conservation of spontaneous Capparis spinosa L. populations from Tunisia. J Nat Conserv 37:96-105

Crozier R (1992) Genetic diversity and the agony of choice. Biol Conserv 61:11-15

Delgado P, Eguiarte LE, Molina-Freaner F, Alvarez-Buylla ER, Pinero D (2008) Using phylogenetic, genetic and demographic evidence for setting conservation priorities for Mexican rare pines. Biodivers Conserv 17:121-137

Earl DA, VonHoldt BM (2012) STRUCTURE HARVESTER: a website and program for visualizing STRUCTURE output and implementing the Evanno method. Conserv Genet Resour 4:359-361

Eguiarte LE, Larson-Guerra J, Nunez-Farfan J, Martınez-Palacios A, Santos del Prado K, Arita HT (1999) Diversidad filogenetica y conservacion: ejemplos a diferentes escalas y una propuesta a nivel poblacional para Agave victoria-reginae en el desierto de Chihuahaua, Mexico. Rev Chil Hist Nat 72:475-492

Ellstrand NC, Elam DR (1993) Population genetic consequences of small size: implications for plant conservation. Annu Rev Ecol Syst 24:217-242

Elsadig LM, Elsadig IA, Mohamed Osman AA, Abuali AI, Marmar AES (2016) Genetic diversity among Sudanese Pearl Millet
(Pennisetum glaucum L.) genotypes using agro-morphological traits and molecular markers (RAPD). Int J Appl Pure Sci Agric 2:51-61

Evanno G, Regnault S, Goudet J (2005) Detecting the number of clusters of individuals using the software structure. A simulation study. Mol Ecol 14:2611-2620

FAO STAT (2005) http://apps.fao.org/.

Faith DP (1992) Conservation evaluation and phylogenetic diversity. Biol Conserv 61:1-10

Fjeldsa J (2000) The relevance of systematics in choosing priority areas for clonal conservation. Environ Conserv 27:67-75

Francis C, Yang Y, Yang R, Boyle T (1999) POPGENE version 1.31: Microsoft Window-based freeware for population genetic analysis. University of Alberta Centre for International Forestry Research, Edmonton

Govindaraj M, Selvi B, Arun Prabhu D, Rajarathinam S (2009) Genetic diversity analysis of Pearl millet (Pennisetum glauccum [L.] R. Br.) accessions using molecular markers. Afr J Biotechnol 8:6046-6052

Gupta SK, Raia KN, Singha P, Ametab VL, Guptac SK, Jayalekhad AK, Mahalae RS, Pareeke S, Swamic ML, Verma YS (2015) Seed set variability under high temperatures during flowering period in Pearl millet (Pennisetum glaucum L. (R.) Br.). Field Crops Res 171:41-53

Hana Y, Jin H, Khaldi A, Kwak M, Lee T, Khaine I, Jang J, Lee H, Kim I, Ahn T, Song J, Song Y, Khorchan A, Stit B, Woo S (2016) Plant diversity in different bioclimatic zones in Tunisia. J Asia-Pac Biodivers 9:56-62

Hu Z, Mbacké B, Perumal R, Guèye MC, Sy O, Bouchet S, Prasad PVV, Morris GP (2015) Population genomics of Pearl millet (Pennisetum glaucum (L.) R. Br.): Comparative analysis of global accessions and Senegalese landraces. BMC Genomics 16:1048

Huenneke LF (1991) Ecological implications of genetic variation in plant populations. In: Falk DA, Holsinger KE (eds) Genetics and conservation of rare plants. Oxford University Press, New York, NY

Holubec V, Vymyslický T, Paprštein F (2010) Possibilities and reality of on-farm conservation. Czech J Genet Plant Breed 46:S60-S64

Kodkany BS, Bellad RM, Mahantshetti NS, Westcott JE, Krebs NF, Kemp JF (2013) Biofortification of pearl millet with iron and zinc in a randomized controlled trial increases absorption of these minerals above physiologic requirements in young children. $\mathrm{J}$ Nutr 143:1489-93

Kumar S, Skjæveland A, Orr RJS, Enger P, Ruden T, Mevik B, Burki F (2009) AIR: a batch-oriented web program package for construction of supermatrices ready for phylogenomic analyses. BMC Bioinformatics 10:357

Lande R (1988) Genetics and demography in biological conservation. Science 241:1455-1459

Lemgharbi M, Badreddine B, Rachid S, Ladjel T, Djafaar D, Boubekeur N (2016) Biodiversity of pearl millet [Pennisetum glaucum (L.) R. Br.] in Southern Algeria (Hoggar Region). Am J Plant Sci 7:1673-1684

Loumerem M, Van Damme P, Reheul D, Behaeghe T (2008) Collection and evaluation of pearl millet (Pennisetum glaucum) germplasm from the arid regions of Tunisia. Genet Resour Crop Evol 55:1017-1028

Liu K, Goodman M, Muse S, Smith JS, Buckler E, Doebley J (2003) Genetic structure and diversity among maize inbred lines as inferred from DNA microsatellites. Genetics 165:2117-2128

Manning K, Pelling R, Higham T, Schwenniger JL, Fuller DQ (2011) 4500-Year old domesticated pearl millet (Pennisetum glaucum) from the Tilemsi Valley, Mali: New insights into an alternative cereal domestication pathway. J Archaeol Sci 38:312-22

Manwaring HR, Bligh HFJ, Yadav R (2016) The challenges and opportunities associated with biofortification of pearl millet 
(Pennisetum glaucum) with elevated levels of grain iron and zinc. Front Plant Sci 7:1944

Mariac C, Luong V, Kapran I, Mamadou A, Sagnard F, Deu M, Chantereau J, Gerard B, Ndjeunga J, Bezancon G, Pham JL, Vigouroux Y (2006) Diversity of wild and cultivated pearl millet accessions (Pennisetum glaucum [L.] R. Br.) in Niger assessed by microsatellite markers. Theor Appl Genet 114:49-58

Marmouzi I, Ali K, Harhar H, Gharby S, Sayah K, El Madani N, Cherrah Y, El Abbes FM (2016) Functional composition, antibacterial and antioxidative properties of oil and phenolics from Moroccan Pennisetum glaucum seeds. J Saudi Soc Agric Sci (in press). https://doi.org/10.1016/j.jssas.2016.04.007

Marshall TC, Slate J, Kruuk LEB, Pemberton JM (1998) Statistical confidence for likelihood-based paternity inference in natural populations. Mol Ecol 7:639-655

May RM (1990) Taxonomy as destiny. Nature 347:129-130

Mhana BY, Mezogi JS, El-Majri MA, Abushoffa AM (2017) Evaluation of pearl millet starch as tablet disintegrant. LIMU J 2:152-163

Moritz C, Faith CP (1998) Comparative phylogeography and the identification of genetically divergent areas for conservation. Mol Ecol 7:419-429

Naino Jika AK, Dussert Y, Raimond C, Garine E, Luxereau A, Takvorian N, Djermakoye RS, Adam T (2017) Unexpected pattern of pearl millet genetic diversity among ethno-linguistic groups in the Lake Chad Basin. Heredity 118:491-502

National Research Council (1996) Lost crops of Africa: volume I: grains. National Academies Press, Washington

Nei M (1978) Estimation of average heterozygosity and genetic distance from a small number of individual. Genetics 90:589-590

Oumar I, Chibani F, Oran SA, Boussaid M, Karamanos Y, Raies A (2005) Allozyme variation among some pearl millet (Pennisetum glaucum L.) cultivars collected from Tunisia and West Africa. Genet Resour Crop Evol 52:1087-1097

Oumar I, Mariac C, Pham JL, Vigouroux Y (2008) Phylogeny and origin of pearl millet (Pennisetum glaucum [L.] R. Br) as revealed by microsatellite loci. Theor Appl Genet 117:489-97

Petit RJ, El Mousadik A, Pons O (1998) Identifying populations for conservation on the basis of genetic markers. Conserv Biol $12: 844-855$

Pritchard JK, Stephens M, Donnelly P (2000) Inference of population structure using multilocus genotype data. Genetics 155:945-959

Pucher A, Hogh-Jensen H, Gondah J, Hash CT, Haussmann B (2014) Micronutrient density and stability in West African pearl millet-potential for biofortification. Crop Sci 54:1709-20

Qi X, Pittaway T, Lindup S, Liu H, Waterman E, Kwame FP, Hash CT, Jiang ZJ, Gale M, Devos KM (2004) An integrated genetic map and a new set of simple sequence repeat markers for pearl millet, Pennisetum glaucum. Theor Appl Genet 109:1485-1493

Radhouane L (2011) Seedling characters at different temperatures in pearl millet (Pennisetum glaucum (L.) R. Br.). Afr J Biotechnol 10:11421-11425

Radhouane L (2014) Allelopathic effect of pearl millet (Pennisetum glaucum) seeds on seedlings growth of three cereals. Int J Inno Sci Res 6:18-24
Raymond M, Rousset F (1995) GENEPOP (version 1.2): population genetics software for exact tests and ecumenicism. J Hered 86:248-249

Santos Del Prado KS (1996) Diversidad y conservación de mamíferos en México: Unenfoque taxonómico yfilogenéico (Dissertation). Universidad Nacional Autónoma de México.

Senthilvel S, Jayashree B, Mahalakshmi V, Sathish Kumar P, Nakka S, Nepolean T, Hash CT (2008) Development and mapping of Simple Sequence Repeat markers for pearl millet from data mining of Expressed Sequence Tags. BMC Plant Biol 8:119

Stich B, Haussmann BI, Pasam R, Bhosale S, Hash CT, Melchinger AE, Parzies HK (2010) Patterns of molecular and phenotypic diversity in pearl millet [Pennisetum glaucum (L.) R. Br.] from West and Central Africa and their relation to geographical and environmental parameters. BMC Plant Biol 10:216

Tako E, Reed SM, Budiman J, Hart JJ, Glahn RP (2015) Higher iron pearl millet (Pennisetum glaucum L.) provides more absorbable iron that is limited by increased polyphenolic content. Nutr $\mathbf{J}$ 14:11

Torres E, Iriondo J, Perez C (2003) Genetic structure of an endangered plant, Antirrhinum microphyllum (Scrophulariaceae): allozyme and RAPD analysis. Am J Bot 90:85-92

Tostain S (1998) Le mil, une longue histoire: hypothèses sur sa domestication et ses migrations. In: Chastanet $M$ (ed) Plantes et paysages d'Afrique, Chapter 16. Une histoire à explorer, Centre de Recherches Africaines, Paris, p 461-490

Vane-Wright RI, Humphries CJ, Williams PH (1991) What to protect? Systematics and the agony of choice. Biol Conserv 55:235-254

Vom Brocke K, Christinck A, Weltzien E, Presterl T, Geiger HH (2003) Farmers' seed systems and management practices determine pearl millet genetic diversity patterns in semi arid regions of India. Crop Sci 43:1680-9

Volis S, Blecher M, Sapir Y (2010) Application of complex conservation strategy to Iris atrofusca of the Northern Negev, Israel. Biodivers Conserv 19:3157-3169

Weir BS, Cockerham CC (1984) Estimating F-statistics for the analysis of population structure. Evolution 38:1358-1370

Whitlock M, McCauley DE (1999) Indirect measures of gene flow and migration: FST ${ }^{1} 1(4 \mathrm{Nm}+1)$. J Hered 82:117-125

Williams PH, Humphries CJ, Vane-Wright RI (1991) Measuring biodiversity: taxonomic relatedness for conservation priorities. Aust Syst Bot 4:665-679

Wilson JP, Burton GW, Zongo JD, Dicko IO (1990) Diversity among pearl-millet landraces collected in central Burkina Faso. Crop Sci 30:40-43

Yang X, Wan Z, Perry L, Lu H, Wang Q, Hao C, Li J, Xie F, Yu J, Cui T, Wang T, Li M, Ge QH (2012) Early millet use in Northern China. Proc Natl Acad Sci USA 109:3726-3730

Zoghlami N, Bouagila A, Lamine M, Hajri H, Ghorbel A (2011) Population genetic structure analysis in endangered Hordeum vulgare landraces from Tunisia: conservation strategies. Afr $\mathbf{J}$ Biotechnol 10:10344-10351 